Artigo Original

http://dx.doi.org/10.1590/0104-07072014000060013

\title{
PSYCOMETRIC CHARACTERISTICS OF THE MORAL DISTRESS SCALE IN BRAZILIAN NURSING PROFESSIONALS ${ }^{1}$
}

\author{
Edison Luiz Devos Barlem², Valéria Lerch Lunardi³, Guilherme Lerch Lunardi', Jamila Geri Tomaschewski- \\ Barlem ${ }^{5}$, Anderson Sousa de Almeida ${ }^{6}$ Carolina Domingues Hirsch ${ }^{7}$
}

\begin{abstract}
${ }^{1}$ Extract from the thesis - Reshaping moral distress in nursing: a foucaultian view, submitted to the Nursing Graduate Program (PPGEnf) of the Universidade Federal do Rio Grande (FURG) 2012.

2 Ph.D. in Nursing. Professor of PPGEnf-FURG. Rio Grande, Rio Grande do Sul, Brazil. E-mail: ebarlem@gmail.com

${ }^{3}$ Ph.D. in Nursing. Professor of PPGEnf-FURG. Rio Grande, Rio Grande do Sul, Brazil. E-mail: vlunardi@terra.com.br

${ }^{4}$ Ph.D. in Administration. Professor of PPGEnf-FURG. Rio Grande, Rio Grande do Sul, Brazil. E-mail: gllunardi@furg.br

${ }^{5}$ Ph.D. Student at PPGEnf-FURG. Scholarship from the Research Support Foundation of the State of Rio Grande do Sul (FAPERGS). Rio Grande, Rio Grande do Sul, Brazil. E-mail: jamila_tomaschewski@hotmail.com

${ }^{6}$ Nursing Undergraduate Student at FURG. Rio Grande, Rio Grande do Sul, Brazil. E-mail: andersalmeida@hotmail.com

${ }^{7}$ Master's Student at PPGEnf-FURG. Rio Grande, Rio Grande do Sul, Brazil. E-mail: hirsch.carolina@gmail.com
\end{abstract}

\begin{abstract}
The Moral Distress Scale was designed to assess the severity and frequency of the moral distress experienced by nursing professionals in everyday situations. The objective of this study was to analyze the psychometric characteristics of the Moral Distress Scale adapted to Brazilian nursing. Through factor analysis, five constructs were identified: lack of competence in the work team; disregard for patient autonomy, inadequate working conditions, denial of the nursing role as an advocate in terminal patients; denial of the nursing role as an advocate of the patient. The proposed pentafactorial solution is statistically and semantically more appropriate to the Brazilian nursing scenario. Based on these results, the scale is considered to be valid and reliable, showing the necessary requirements regarding convergent and discriminating validity as well as internal consistency to be used while evaluating the intensity and frequency of moral distress in Brazilian nursing professionals.
\end{abstract}

DESCRIPTORS: Validation studies. Burnout, professional. Ethics. Nursing.

\section{CARACTERÍSTICAS PSICOMÉTRICAS DA MORAL DISTRESS SCALE EM PROFISSIONAIS DE ENFERMAGEM BRASILEIROS}

RESUMO: A Escala de Sofrimento Moral foi projetada para avaliar intensidade e frequência de sofrimento moral vivenciado por profissionais de enfermagem a partir de situações cotidianas. Objetivou-se analisar as características psicométricas da Escala de Sofrimento Moral adaptadas para a enfermagem brasileira. A análise estatística permitiu identificar cinco constructos: falta de competência na equipe de trabalho, desrespeito à autonomia do paciente, condições de trabalho insuficientes, negação do papel da enfermagem como advogada do paciente na terminalidade e negação do papel da enfermagem como advogada do paciente. A solução pentafatorial proposta demonstra maior adequação estatística e semântica ao contexto de enfermagem brasileiro. Com base nos resultados encontrados, considera-se que a escala é válida e fidedigna, demonstrando os requisitos necessários quanto às validades convergente e discriminante, bem como de consistência interna para ser utilizada na avaliação da intensidade e frequência do sofrimento moral em profissionais de enfermagem brasileiros.

DESCRITORES: Estudos de validação. Esgotamento profissional. Ética. Enfermagem.

\section{CARACTERÍSTICAS PSICOMÉTRICAS DE LA MORAL DISTRESS SCALE EN PROFESIONALES DE ENFERMERÍA EN BRASIL}

\begin{abstract}
RESUMEN: La escala del sufrimiento moral fue proyectada para evaluar la intensidad y frecuencia del sufrimiento moral vividos por los profesionales de enfermería a partir de situaciones cotidianas. Se objetivó analizar las características psicométricas de la escala adaptadas para la enfermería brasileña. A través del análisis factorial, se identificaron cinco construcciones: falta de competencia en el equipo de trabajo; desprecio por la autonomía del paciente; condiciones de trabajo inadecuadas; negación del papel del enfermero como abogado del paciente en fase terminal; y negación del papel de la enfermería como abogados del paciente. La solución con cinco factores propuesta demostró mayor adecuación estadística y semántica al contexto de enfermería brasileña. Con base en los resultados encontrados, se considera que la escala es válida y fiable, ya que muestra los requisitos necesarios cuanto a la validez convergente y discriminante, bien como a la consistencia interna para ser utilizada en la evaluación de la intensidad y frecuencia del sufrimiento moral en profesionales de enfermería brasileña.
\end{abstract}

DESCRIPTORES: Estudios de validación. Agotamiento profesional. Ética. Enfermería. 


\section{INTRODUCTION}

In the professional context of nursing, Moral Distress (MD) was first described in the 1980s, and it can be expressed as the suffering resulting from the inconsistency between workers' actions and their personal convictions. ${ }^{1}$ Hence, MD can be defined as the feeling arising from the inconsistency between people's actions and their beliefs. The person knows what is right, but it is almost impossible to take this action, which may, in this situation, contribute to errors of judgment, personal failures, character weaknesses or even circumstances beyond personal control..$^{2-3}$

Aiming to identify MD in nursing professionals, most studies conducted on the subject, up to the present day, researched it using a qualitative approach, interviewing professionals, individually or in small groups. ${ }^{4}$ Feelings of anger and sadness were most cited in literature as bio-psychosocial effects caused by MD, with introspection being the major characteristic of nursing workers who receive little or no support for coping with their conflicts. ${ }^{5}$

These feelings, which result in MD, can lead to emotional responses in the individual, such as dissatisfaction with the work, reluctance to go to work or even abandonment of the profession. ${ }^{6-7}$ Faced with the situation of living with MD, the nurses report that this experience does not compromise the care they provide, however, what is perceived is a remoteness from situations in which the patient needs support and protection, with weaknesses in the care provided. ${ }^{5}$

MD can lead nurses to trivialize everyday situations, negating possible damages to the patient and, consequently, these workers may abandon their principles based on fear, for convenience or self-preservation. ${ }^{8}$ Nevertheless, each individual may perceive situations that arise in their lives differently, being singular, complex and different from others.

Unlike qualitative approaches, an instrument called Moral Distress Scale (MDS) ${ }^{9}$ has been applied in quantitative studies in different realities. ${ }^{8,10-15}$ Its questions are focused on dilemmas, ethical problems, unnecessary treatment, unsafe working conditions, among others, allowing to identify the experience of many behaviors related to MD in different cultures.
HISTORY AND DEVELOPMENT OF THE MORAL DISTRESS SCALE

The most broadly used instrument for measuring MD in nursing is the MDS, being first presented in 1995, when it was applied to 111 nurses who worked in the ICU ${ }^{16}$ and later in 2001, applied to 214 nurses from different units, active in North American hospitals. ${ }^{9}$ Its construction was based on three fundamental assumptions: that nurses apply their personal values to their work environments; that nursing professionals can identify the existence of ethical issues in their everyday professional life; and that professional nurses can assess the extent of MD experienced in their everyday lives. ${ }^{9}$

Initially, the instrument had 32 questions, operationalized by using a seven-point likert scale, ranging from 1 (for never occurs) to 7 (for very intense distress), without discriminating, hitherto, frequency and intensity. It encompassed issues that focused on prolonging life, performing unnecessary tests and treatment, incompetent professional actions by the medical staff and situations of omission against patients. ${ }^{16}$

As this instrument had no questions regarding pain management, administration of the nursing care and incompetence of nursing professionals, a review of the MDS was proposed, operationalized with 38 questions in two scales, the first for the intensity of distress and the second for the frequency of MD occurrence, both ranging from 0 (for never occurs or no frequency) to 6 (for very intense distress or very frequent).

In Brazil, the first adaptation and validation of the MDS occurred in $2009,{ }^{14}$ when it was concluded that the instrument did not seem to have sufficiently explored MD related to problems experienced by the nursing staff in their work environment, in the Brazilian reality, many of them related to organizational issues that have been identified in other studies, such as insufficient professional staff, poor resource materials, ${ }^{17-19}$ and lack of professional autonomy. ${ }^{20}$

Hence, in view of the importance of continuing to use the MDS, to research on the experience of MD by the nursing staff in Brazil, the aim of this study was to examine the psychometric characteristics of the MDS adapted to Brazilian nursing, through an adaptation of the original instrument, culturally validated to the Portuguese language. ${ }^{14}$ 


\section{METHOD}

This is a quantitative, exploratory, descriptive study, using a cross-sectional design. The nonprobabilistic convenience sample consisted of 247 nursing professionals, with 47 nurses, 169 nursing technicians and 31 nursing assistants, working in two different hospitals, one philanthropic and the other public. Most of the subjects were women $(85.8 \%)$ and worked in the philanthropic hospital $(72.9 \%)$. The mean age of the subjects was 33.5 years old ( \pm 9.16$)$; the mean time working in the profession and the mean time working in the unit in which they worked, at the time of data collection, were 5.8 years and 4.0 years $( \pm 6.1$ and \pm 4.7$)$, respectively.

Of the 47 nurses, 13 had only an undergraduate degree; 23 had completed specialization courses; and 11 had a master's degree. Regarding the 200 nursing technicians and nursing assistants, 141 had completed only a medium-level course; 18 had completed an undergraduate course; 27 had completed post-technical courses; 13 had completed short courses; and one professional had completed a graduate course.

This study employed the MDS, ${ }^{9}$ an instrument that had already been replicated in other settings in several international studies, ${ }^{8,10-13}$ and also in Brazil. ${ }^{14}$ Nevertheless, as the instrument applied in Brazil was insufficient to analyze different problems experienced by the nursing staff related to MD in their work environment, a new questionnaire with 39 questions was proposed, 21 from the original MDS, already adapted to the Portuguese language, ${ }^{14}$ and 18 coming from knowledge produced by other national studies. ${ }^{17,19}$

The questionnaire was applied in two versions; one for nurses and the other for nursing technicians and nursing assistants, differing only in the initial items related to characterization. At the end of the instruments, a question was inserted seeking to identify if, in general, situations experienced at work caused MD, measured equally in seven-point Likert scales.

Before its implementation, a pilot study with 30 nursing professionals, with similar characteristics to the study population, was conducted comprehensively seeking to validate the contents of the proposed questions and the questionnaire. The instrument was easy to understand and complete, with no need to adapt the language and an average time of 20 minutes being used to complete it.

The insertion in the fields for collection occurred gradually, with a first moment of identifi- cation and recognition of the physical area in the institutions, after the delivery and collection of the instruments took place. Visiting the units was adopted as the procedure for delivery, initially carrying out the personal presentation of the collectors previously trained by the nursing staff, briefly describing the research objectives, reading the first page of the instrument and explaining how to complete it. The instrument was self-administered and it was delivered directly to respondents in a brown envelope with no identification. During the delivery, the ethical procedures were explained.

After the distribution of the questionnaires, the collection schedule was proceeded to. At this stage, a maximum of five attempts at different locations was defined, for the search of previously delivered instruments. The research was approved by the Ethics Committee of the researchers' institutional affiliations, with all ethical procedures being carried out (Report n. 70/2010).

The data were subjected to three different analyses: 1) exploratory factor analysis, seeking the reduction and summarization of data; 2) descriptive analysis, aiming at obtaining the mean and standard deviation between the respondent groups; and 3) variance analysis, in order to obtain correlation values for the constructs. SPSS statistical software version 13.0 (Statistical Package for Social Sciences) was used at the data analysis stage.

A total of 350 questionnaires were delivered to the nursing staff at these institutions, 90 for nurses, 210 for nursing technicians and 60 for nursing assistants, with 291 being returned, representing an $83.14 \%$ return rate. 44 instruments were excluded, with seven from nurses, 27 from nursing technicians and ten from nursing assistants, either by being inaccurate in the marking of questions, dichotomous scale (zero to six) or being blank, with the final sample consisting of 247 questionnaires, with 47 nurses, 169 nursing technicians and 31 nursing assistants.

The validation process of the instrument sought to ensure one-dimensionality by examining whether the observable variables for each construct had an acceptable setting on a single factor; convergent validity, identifying whether the observable variables of a construct were related to each other; and discriminant validity by examining if the observable variables of a construct were related to other constructs. Therefore, the factor analysis was performed using the method of main components, and Cronbach's alpha to assess the reliability of the scales. 


\section{RESULTS}

Initially, 39 questions were submitted to exploratory factor analysis (between blocks) seeking to verify the discriminant validity of the instrument. This was defined as the method for extracting the analysis of the main components, applying the Varimax orthogonal rotation to better discriminate the relevance of the variables to the identified components. The formation of the factors followed two criteria: the degree of association between variables, found through the factor loads; and their degree of subjectivity.

The first group suggested the formation of seven constructs, making it difficult to categorize, according to the proposed theoretical framework. Thus, there was the process of gradual exclusion of each of the issues that had low correlations in their blocks, or which did not adhere conceptually to the constructs formed, so as to facilitate the grouping of questions.

As questions were being eliminated and constructs became clearer, pentafactorial training was defined as the extraction solution, using the division of the components from the fifth construct with an eigenvalue equal to 0.840 (eigenvalue $\geq$ 0840) and considering factorial loadings greater than 0.400 as the cut-off point. Conceptually, the main criterion to define the number of constructs to be extracted is to consider only those with eigenvalues greater than 1 , since each variable contributes to a value of 1 of the total eigenvalue.
Thus, any single factor variance should explain at least one variable, if it was kept for interpretation. Nevertheless, in practice, most researchers rarely use a single criterion to determine how many factors should be extracted; the selection of the number of constructs should also consider the conceptual structure of the research and its interpretation. ${ }^{21}$ At the end of this analysis, 15 questions were excluded for having low correlations with other items in their group, and one question (q-35) was excluded for not presenting conceptual adherence in its block.

Subsequently, an exploratory factor analysis (in blocks) was performed in order to observe the one-dimensionality of the constructs. Few researchers have made use of this type of analysis in blocks, which is unfortunate, since the result is quite informative. It was possible to identify the items of each construct, analyzed together and converged to a single factor, suggesting that they are all one-dimensional.

A final assessment of the reliability of the instrument was performed using Cronbach's alpha, not suggesting the elimination of other items in the questionnaire. The reliability coefficient of the instrument showed a value of 0.95 , whereas the coefficients of the factors were between 0.79 and 0.91 , values considered high for exploratory studies, thus demonstrating the reliability of the MDS in the selected sample. In its final version, the instrument presented five constructs, consisting of 23 items.

Table 1 - Definitions of variables used in the data analysis. Rio Grande-RS, 2012

\begin{tabular}{|c|c|}
\hline Variable & Definition \\
\hline $\begin{array}{l}\text { Lack of competence in the } \\
\text { work team }\end{array}$ & $\begin{array}{l}\text { Lack of skill or technical expertise that should exist to perform a specific action for } \\
\text { each professional category. }{ }^{10}\end{array}$ \\
\hline $\begin{array}{l}\text { Disregard for the patient's } \\
\text { autonomy }\end{array}$ & $\begin{array}{l}\text { Disregard for the patient's self-government, liberty, privacy, individual choice and } \\
\text { freedom of will. }{ }^{6}\end{array}$ \\
\hline $\begin{array}{l}\text { Inadequate working condi- } \\
\text { tions }\end{array}$ & $\begin{array}{l}\text { Lack of material and/or human conditions for the completion of the nursing } \\
\text { work. } .^{22}\end{array}$ \\
\hline $\begin{array}{l}\text { Denial of nursing as an } \\
\text { advocate for the terminally } \\
\text { ill patient }\end{array}$ & $\begin{array}{l}\text { Unused potential by nursing to vindicate the rights of patients in the terminally ill } \\
\text { process. }{ }^{23}\end{array}$ \\
\hline $\begin{array}{l}\text { Denial of nursing as an } \\
\text { advocate for the patient }\end{array}$ & Unused potential by nursing to vindicate the rights of patients. ${ }^{23}$ \\
\hline
\end{tabular}


Psycometric characteristics of the moral distress scale in brazilian...

Table 2 - Exploratory factor analysis (Varimax rotation). Rio Grande-RS, 2012

Indicators
Lack of competence in the work team
q-18. Providing assistance to a physician who, in your opinion, is acting
incompetently as regards the patient.
q-25. Working with nursing technicians/assistants who do not possess
the necessary competence that the patient's condition requires.
q-29. Working with nurses who do not have the competency to perform.
q-31. Working with physicians who do not have the competency to per-
form.
q-32. Working with support services which do not have the competency
to perform.
q-33. Working with medical or nursing students who do not have the
competency to perform.

\section{Disregard for the patient's autonomy}

q-04. Providing assistance to a physician who is performing a procedure on the patient, without informed consent, even from the family.

q-21. Complying with the request of the physician not to discuss with the patient regarding their resuscitation, in case of cardiac arrest.

q-22. Complying with the request of the physician not to discuss resuscitation with the family of the patient, in case of cardiac arrest, when the patient is devoid of discernment.

$\mathrm{q}-23$. Complying with the request of the physician not to talk about death with a dying patient who asks about dying.

\section{Inadequate working conditions}

q-06. Not having the materials necessary to provide patient care.

q-08. Not having the equipment necessary to meet the urgent needs of a patient.

q-14. Needing to prioritize patients to be cared for due to the lack of human resources.

q-15. Needing to delegate nursing care to family members of patients due to insufficient human resources.

Denial of the nursing role as an advocate for the terminally ill patient q-34. Avoiding taking action in situations of patient death associated with malpractice.

q-36. Performing with professionals who do not explain to the patient their health status and disease.

q-37. Initiating intensive procedures to save a life when the terminal patient has expressed the wish to die.

q-38. Avoiding taking measures when the abandonment of the dying patient can be seen by the healthcare team.

q-39. Avoiding taking measures when the abandonment of the dying patient can be seen by the family.

Denial of the nursing role as an advocate for the patient

q-10. Allowing medical students to perform painful procedures on patients just to hone their skills.

q-11. Providing assistance to physicians who are performing procedures on patients after cardio-respiratory recovery was not satisfactory.

q-16. Observing, without taking action, when the nursing staff does not respect patient privacy.

q-17. Obeying physician's orders not to tell the patient the truth, even when the patient asks you for the truth.

$\begin{array}{llllll}\text { Block } & \text { F1 } & \text { F2 } & \text { F3 } & \text { F4 } & \text { F5 }\end{array}$

.623

$\begin{array}{llllll}.670 & .710 & .150 & .250 & .203 & .200 \\ .737 & .738 & .262 & .257 & .155 & .182 \\ .768 & .722 & .219 & .240 & .329 & .182 \\ .787 & .746 & .296 & .150 & .323 & .123 \\ .716 & .692 & .306 & .156 & .337 & .074\end{array}$

.558

.-129

.527

.394

.256

.208

.781

.266

.828

130

.083

.027

.785

.290

.795

.037

.166

.664

.265

.678

.206

.189

.237

.697

.192

.145

.769

.217

.018

.635

.347

.000

.655

.245

.158

.681

.336

.126

.649

.320

.292

.582

.130

.285

.603

.077

.236

.504

.41

.076

.110

.439

.168

.693

.24

.353

.210

.661

.167

.666

.27

.414

.052

.579

.290

.752

.441

.117

.233

.667

.211

.844

.401

.097

.212

.777

.676

.422

.087

.362

.288

.554

.766

$\begin{array}{llll}.092 & .202 & .068 & .231\end{array}$

.812

.653

.302

.320

.341

.129

.514

.614

.405


Barlem ELD, Lunardi VL, Lunardi GL, Tomaschewski-Barlem JG, Almeida AS

\begin{tabular}{|c|c|c|c|c|c|}
\hline Initial Eigenvalue & 11.08 & 1.56 & 1.40 & .958 & .840 \\
\hline$\%$ variance explained - rotated $(68.99 \%)$ & 48.20 & 6.80 & 6.10 & 4.16 & 3.65 \\
\hline Cronbach's alpha (0.95 instrument) & .91 & .79 & .79 & .88 & .82 \\
\hline \multicolumn{6}{|c|}{ KMO measure of sampling adequacy $(\mathrm{KMO}=0.941)$} \\
\hline $\begin{array}{l}\text { Bartlet test: chi-square }=3305.983 \\
\text { Correlation matrix determinant }(1.63)\end{array}$ & & & & & \\
\hline
\end{tabular}

After the validation stage of the instrument, descriptive analyses were carried out in order to evaluate the intensity and frequency $(\mathrm{Fq})$ of $\mathrm{MD}$ experienced by the nursing professionals studied.

Table 3 - Mean, standard deviation and correlation values for the constructs. Rio Grande-RS, 2012

\begin{tabular}{ccccccccccc}
\hline & M & SD & Fq & SD & A & B & C & D & E \\
\hline A & 4.36 & 1.26 & 2.57 & 1.19 & - & $.576^{*}$ & $.661^{*}$ & $.779^{*}$ & $.718^{*}$ \\
B & 3.77 & 1.26 & 1.98 & 1.26 & $.576^{*}$ & - & $.514^{*}$ & $.578^{*}$ & $.598^{*}$ \\
C & 4.09 & 1.24 & 2.54 & 1.30 & $.661^{*}$ & $.514^{*}$ & - & $.589^{*}$ & $.653^{*}$ & \\
D & 4.14 & 1.30 & 2.26 & 1.25 & $.779^{*}$ & $.578^{*}$ & $.589^{*}$ & - & $.665^{*}$ \\
E & 4.19 & 1.23 & 2.37 & 1.33 & $.718^{*}$ & $.598^{*}$ & $.653^{*}$ & $.665^{*}$ & - \\
MD & 4.11 & 1.25 & 2.34 & 1.31 & - & - & - & - & - \\
\hline
\end{tabular}

* Correlation significant at the 0.01 level.

A) Lack of competence in the work team; B) Disregard for patient autonomy; C) Inadequate working conditions; D) Denial of the nursing role as a advocate for the terminally ill patient; E) Denial of the nursing role as a patient advocate; MD) Moral distress.

The "lack of competence in the work team" dimension had the highest perceived mean of MD (4.36), and frequency (2.57) experienced by the nursing professionals surveyed. Whereas "denial of the nursing role as a patient advocate" (4.19; $\mathrm{Fq}=2.37)$ and also in the "terminally ill" (4.14; Fq=2.26), followed by "inadequate working conditions" (4.09; $\mathrm{Fq}=2.54)$ appear in the intermediate group. In turn, the "disregard for patient autonomy" (3.77; Fq=1.98) appeared as the dimension with less intensity and frequency of MD experienced by the study participants.

By observing Pearson's correlation coefficients, the relation between the "lack of competence in the work team" and "denial of the nursing role as an advocate in the terminally ill patient" $(\mathrm{r}=0.779, \mathrm{p}<0.001)$ appears as the most significant, followed by the correlation between "lack of competence in the work team" and "denial of the nursing role as a patient advocate" $(\mathrm{r}=0.718, p<0.001)$. The lower correlations, although quite high, were between "disregard for patient autonomy" and "insufficient working conditions" $(\mathrm{r}=0.514, \mathrm{p}<0.001)$, followed by the correlation between "disregard for patient autonomy" and "lack of competence in the work team" ( $\mathrm{r}=0.576, p<0.001)$. It is noteworthy that all correlations tested had positive and statistically significant associations, at the level of $1 \%$, demonstrating that the proposals to evaluate the MD in the Brazilian context dimensions are strongly correlated.

\section{DISCUSSION}

As evidenced in the results presented, the distribution of the MDS, in the version applied in this study, is justified by the greater range of everyday situations that may possibly trigger moral distress among the nursing staff of two hospitals, with five constructs that, in relation to the conceptual framework and definition, are distinct from the results obtained in previous studies, ${ }^{9,}{ }^{14}$ with tri-factorial and tetra-factorial solutions.

Taking into account the theoretical foundation of $\mathrm{MD}^{1}$ and the assumptions used in the development and expansion of the original MDS,, ${ }^{16}$ the instrument validated in this study showed higher theoretical adherence, highlighting five dimensions associated with MD. The final version of the instrument consisted of 23 items, with 10 questions being kept from the original MDS and 13 arising from the knowledge produced in other national studies (Table 4). 
q-01. Performing improvisations to face the lack of material in the care of patients.

q-02. Following the family's wishes in order to maintain the patient's life, although it is not the best for him/her.

q-03. Avoiding taking measures to find leftover medicines in the patient's box.

q-04. Providing assistance to a physician who is performing a procedure on the patient, without informed consent, even from the family.

q-05. Initiating intensive procedures to save a life, when you believe that they only delay death.

q-06. Not having the materials necessary to provide patient care.

q-07. Ignoring situations where the patient was not given the appropriate information to ensure their informed consent.

$\checkmark$ q-08. Not having the equipment necessary to meet the urgent needs of a patient.

q-09. Avoiding taking measures to discover that a member of the nursing team applies the wrong medication and fails to report it.

$\checkmark$ q-10. Allowing medical students to perform painful procedures on patients just to hone their skills.

$\checkmark$ q-11. Providing assistance to physicians who are performing procedures on patients after cardio-respiratory recovery was not satisfactory.

q-12. Performing medical prescriptions to conduct unnecessary tests and treatments in terminally ill patients.

q-13. Working with the nursing staff at a level considered to be "unsafe".

$\checkmark$ q-14. Needing to prioritize patients to be cared for due to the lack of human resources.

$\checkmark$ q-15. Needing to delegate nursing care to family members of patients due to insufficient human resources.

$\checkmark$ q-16. Observing, without taking action, when the nursing staff does not respect patient privacy.

q-17. Obeying physician's orders not to tell the patient the truth, even when the patient asks you for the truth.

$\checkmark$ q-18. Providing assistance to a physician who, in your opinion, is acting incompetently as regards the patient.

q-19. Demanding better working conditions for the care of patients.

q-20. Performing with professionals who do not respect patients' demonstrations on the nursing care.

q-21. Complying with the request of the physician not to discuss with patients regarding their resuscitation, in case of cardiac arrest.

q-22. Complying with the request of the physician not to discuss resuscitation with the family of the patient, in case of cardiac arrest, when the patient is devoid of discernment.

q-23. Complying with the request of the physician not to talk about death with a dying patient who asks about dying.

q-24. Working with nurses who do not possess the necessary competence that the patient's condition requires.

$\checkmark$ q-25. Working with nursing technicians/assistants who do not possess the necessary competence that the patient's condition requires.

q-26. Working with medical or nursing students who do not possess the necessary competence that the patient's condition requires.

q-27. Working with physicians who do not possess the necessary competence that the patient's condition $x$ requires.

q-28. Working with support services which do not possess the necessary competence that the patient's condition requires.

$\checkmark$ q-29. Working with nurses who do not have the competency to perform.

q-30. Working with technicians/assistants who do not have the competency to perform.

$\checkmark$ q-31. Working with physicians who do not have the competency to perform.

$\checkmark$ q-32. Working with support services which do not have the competency to perform. 


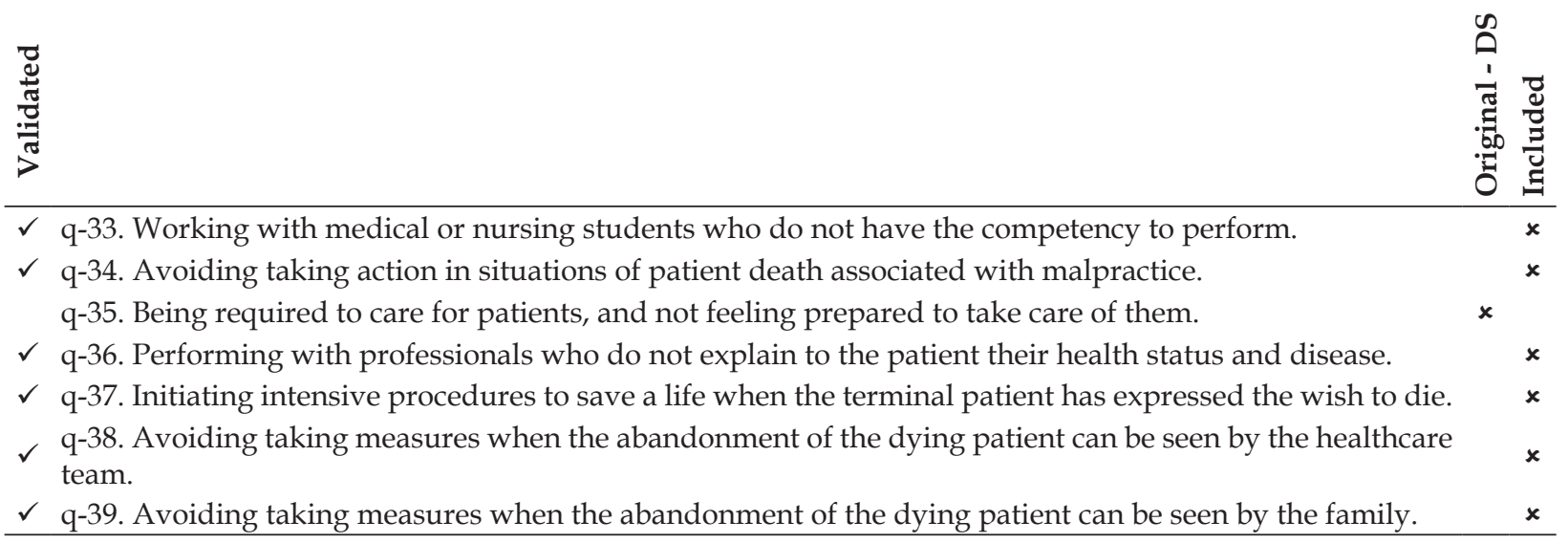

In comparison to international studies evaluating $\mathrm{MD}$, the instrument used in this study had higher means for the application of the MDS used in the English language. ${ }^{9}$ In a study with American nurses, it appears that the mean intensity of MD was 3.64 (ranging from 2.61 to 4.79 ) and a frequency equal to 1.45 (ranging from 0.08 to 3.54 ), whereas in the present study, the mean intensity of MD was higher, equal to 4.11 (ranging from 3.77 to 4.36 ) and a frequency of 2.34 (ranging from 1.98 to 2.57). When compared to the first version validated in Brazil in 2009, ${ }^{14}$ differences with the present study (although small) are also observed, with a mean intensity of MD equal to 4.0 (ranging from 3.55 to 4.55 ) and a frequency of 1.95 (ranging from 1.42 to 2.42 ) being obtained from the first Brazilian version of the MDS.

Regarding the use of factor analysis and training of constructs in its initial implementation, during the development of the MDS, ${ }^{9} 30$ questions, divided into three constructs were validated and denominated thus: "Individual responsibility", with 20 items (mean intensity of distress $=4.98$ and Cronbach's alpha equal to 0.98); "not in the best interest of the patient", with seven items (mean intensity of distress $=4.93$ and Cronbach's alpha of 0.82) and "disappointment" with three items (mean intensity of distress $=4.34$ and Cronbach's alpha equal to 0.84 ). The total variance explained by this instrument was $19.38 \%{ }^{16}$

In the first Brazilian implementation in $2009,{ }^{14}$ conducted only with nurses, 21 questions were validated, divided into four factors and denominated thus: "Lack of competence in the work team", with six items (mean intensity of distress 4.55; frequency 2.42 and Cronbach's alpha 0.89), followed by "denying the role of the nurse as a patient advocate", with 8 items (mean intensity of distress 4.30; frequency 1.71; and Cronbach's alpha 0.91), "therapeutic obstinacy" with 3 items (mean intensity of distress 3.60; frequency 2.26; and Cronbach's alpha 0.68) and "disregard for patient autonomy", with 4 items (mean intensity of distress 3.57; frequency 1.42; and Cronbach's alpha 0.82 ). The total variance explained by this instrument was $66.71 \%$, quite similar to the present study, which showed a total variance of $68.99 \%$.

Important differences can still be highlighted when comparing different studies performed using the MDS in other countries. ${ }^{24-26}$ In Japan, a version of the MDS for nurses working in the mental health field has demonstrated the existence of MD attributed to three factors denominated by the authors of: "Unethical conduct of caregivers"; "insufficient professional staff"; and "acquiescence in the violation of patients' rights". In this MDS application, comprising 24 original MDS questions plus 19 questions prepared by Japanese authors, MD was considered too low by their authors, and not comparable with other studies that used the MDS, however, the "insufficient professional staff" factor proved to be the most potentially related to MD in Japanese nursing. ${ }^{25}$

In a study with Iranian nurses, it could be detected that a hierarchical environment, so as to favor the medical staff, following a traditional model of work organization, can influence the experience of MD more negatively. In this study, the concepts of hierarchy, order, power imbalance and following the physician's orders showed that the physician can influence MD negatively. ${ }^{13}$

The differences between the studies show singularities in the application of the MDS in different environments, highlighting its use in professional environments of American, ${ }^{9,16}$ Japanese, ${ }^{2,25}$ Iranian ${ }^{13}$ or Brazilian nursing as in the case in this 
study. It is possible to perceive that the environments and the way the work is organized can reflect on the experience of different situations of MD. ${ }^{26}$ Thus, subjects in different environments and societies can experience MD uniquely, with special attention being needed to better evaluate the experience.

\section{FINAL CONSIDERATIONS}

The results obtained showed that the scale proposed for the Brazilian context is valid and applicable to all professionals in the nursing team. This study allowed for the identification of five dimensions, which explain more broadly MD in the Brazilian context: lack of competence in the work team; disregard for patient autonomy, inadequate working conditions, denial of the role of nurses as an advocate for the terminally ill patient, and denial of the nursing role as a patient advocate. Lack of competence in the work team appeared as the factor of greater intensity and frequency of MD experienced by study participants, whereas disregard for patient autonomy appeared as the one with lower intensity and frequency.

When compared to other studies, the MD identified among Brazilian nursing professionals appeared as higher both in intensity and frequency. Recurrent situations of the inadequate technical competence of the team of health workers and the lack of material and human conditions necessary for the safe performance of nursing work both for patients and for the workers, as well as recognition of the condition of patients as subjects entitled to exercise their autonomy and consent of nursing as to not deny the rights of patients are factors that cause MD, with them being possibly more intense in the Brazilian context than in other contexts.

As the main limitation of the study, the sample selected for this study belong to the same cultural and social context of two hospitals in a city in southern Brazil, differing only in relation to the legal character of the institutions to which they belonged, with one being a public hospital and the other philanthropic. Although the analyzed sample is representative in statistical terms, the interpretation of descriptive results should not be generalized to other contexts than the institutions studied. This weakness is relative to descriptive analysis and not to the validation process of the instrument.

Finally, the need for further studies applying the adapted instrument in this research in other places in Brazil can be highlighted, checking whether, or not, significant differences that affect the understanding of the intensity and frequency of MD exist.

\section{REFERENCES}

1. Jameton A. Nursing practice: the ethical issues. New Jersey (US): Taylor Print Hall; 1984.

2. Hardingham LB. Integrity and moral residue: nurses as participants in a moral community. Nurs Philos. 2004 Jan; 5(1):127-34.

3. Kopala B, Burkhart L. Ethical dilemma and moral distress: proposed new NANDA diagnoses. Int J Nurs Terminol Classif. 2005 Jan-Mar; 16(1):3-13.

4. McCarthy J, Deady R. Moral distress reconsidered. Nurs Ethics. 2008 Mar; 15(2):254-62.

5. Gutierrez KM. Critical care nurses' perceptions of and responses to moral distress. Dimens Crit Care Nurs. 2005 Set-Out; 24(5):229-41.

6. Corley MC. Nurse moral distress: a proposed theory and research agenda. Nurs Ethics. 2002 Nov; 9(6):636-50.

7. Elpern EH, Covert B, Kleinpell R. Moral distress of staff nurses in a medical intensive care unit. Am J Crit Care. 2005 Nov; 14(6):523-30.

8. Hamric AB, Blackhall LJ. Nurse-physician perspectives on the care of dying patients in intensive care units: collaboration, moral distress, and ethical climate. Crit Care Med. 2007 Fev; 35(2):422-9.

9. Corley MC, Elswick RK, Gorman M, Clor T. Development and evaluation of moral distress scale. J Adv Nurs. 2001 Jan; 33(2):250-6.

10. Corley MC, Ptlene M, Elswick RK, Jacob M. Nurse moral distress and ethical work environment. Nurs Ethics. 2005 Jul; 12(4):381-90.

11. Mobley MJ, Mohamed YR, Verheijde JL, Patel B, Larson JS. The relationship between moral distress and perception of futile care in the critical care unit. Intens Crit Care Nurs. 2007 Out; 23(1):256-63.

12. Zuzelo RP. Exploring the moral distress of registered nurses. Nurs Ethics. 2007 Mai; 14(3):343-59.

13. Khoiee EM, Vaziri MH, Alizadegan S, Motevallian AS, Kashani OMR, Goushegir SA, et al. Developing the Moral Distress Scale in the population of Iranian nurses. Iran J Psychiatry. 2008; 3(1):55-8.

14. Barlem ELD, Lunardi VL, Lunardi GL, Dalmolin GL, Tomaschewski JG. Vivência do sofrimento moral na enfermagem: percepção da enfermeira. Rev Esc Enferm USP. 2012 Jun; 46(3):681-8.

15. Sporrong SK, Höglund AT, Arnetz B. Measuring moral distress in pharmacy and clinical practice. Nurs Ethics. 2006 Jul;13(4):416-27.

16. Corley MC. Moral distress of critical care nurses. Am J Crit Care. 1995 Jul; 4(1):280-5. 
17. Barlem ELD, Lunardi VL, Tomaschewski-Barlem JG, Lunardi GL, Lunardi Filho WD, Schwonke CRGB. Moral distress: challenges for an autonomous nursing professional practice. Rev Esc Enferm USP. 2013 Abr; 47(2):506-10.

18. Barlem ELD, Lunardi VL, Lunardi GL, Tomaschewski-Barlem JG, Silveira RS. Sofrimento moral no cotidiano da enfermagem: traços ocultos de poder e resistência. Rev Latino-Am Enferm. 2013 Jan; 21(1):293-99.

19. Barlem ELD, Lunardi VL, Fialho AR, Silveira RS. Percepções, sentimentos e dificuldades da equipe de enfermagem no cuidado a pacientes terminais idosos. Enferm Bras. 2006; 5(1):289-98.

20. Barlem ELD, Lunardi VL, Lunardi GL, TomaschewskiBarlem JG, Silveira RS, Dalmolin GL. Sofrimento moral em trabalhadores de enfermagem. Rev LatinoAm Enferm. 2013 Jan-Fev; 21(spec):79-87.
21. Hair JF, Black WC, Babin BJ, Anderson RE, Tatham RL. Análise multivariada de dados. Porto Alegre (RS): Bookman; 2009.

22. Lunardi Filho WD. O mito da subalternidade do trabalho da enfermagem à medicina. Pelotas (RS): Editora e Gráfica Universitária UFPel; 2004.

23. Dejours C, Abdoucheli E, Jayet C. Psicodinâmica do trabalho. São Paulo (SP): Atlas; 2011.

24. Grace PJ. Professional advocacy: widening the scope of accountability. Nurs Philos. 2001 Jul; 2(2):151-62.

25. Ohnishi K, Ohgushi Y, Nakano M, Fuji H, Tanaka $\mathrm{H}$, Kitaoka K, et al. Moral distress experienced by psychiatric nurses in Japan. Nurs Ethics. 2010 Nov; 17(6):726-40.

26. Range LM, Rotherham AL. Moral distress among nursing and non-nursing students. Nurs Ethics. 2010 Mar; 17(2):225-32. 